\title{
Yoga, Psychophysiology, and Health: Studies from the Yoga Department Research, Patanjali University, India
}

\author{
Carolina Baptista Menezes ${ }^{1}$ \\ Faculdade de Psicologia, Universidade Federal de Pelotas, Pelotas, Brasil \\ Lisiane Bizarro \\ Laboratory of Experimental Psychology, Neuroscience and Behavior, \\ Universidade Federal do Rio Grande do Sul, Porto Alegre, Brasil \\ Shirley Telles \\ Yoga Research Department of the Patanjali Research Foundation, Haridwar, India
}

\begin{abstract}
Techniques such as yoga postures, regulated breathing, relaxation, and meditation have increasingly become investigated in mainstream science. Many of these studies are carried out in India, where most of the practices originated. Here is a report of a professional experience concerning a research internship in the Yoga Research Department from Patanjali University, India, where some of these studies have been conducted. The presented results, which derive from the investigations carried out in the aforementioned department, indicate that such practices can have clinical implications for mental and physical health. Concerning physiology, depending on the particular technique, benefits have been noted during, immediately after or some time following the practice. Likewise, both short and long term interventions may produce positive therapeutic changes. However, this is not consistent to all conditions, hence the need to systematically investigate their applications. Psychophysiological changes seem to accompany many of these effects and this is an area that warrants more investigation, especially in Brazil, constituting an emergent field linking the aforementioned techniques, psychology and neuroscience.
\end{abstract}

Keywords: Psychophysiology, yoga, respiration, meditation.

\section{Yoga, Psicofisiologia e Saúde: Estudos do Departamento de Pesquisas em Yoga da Universidade Patanjali, Índia}

\section{Resumo}

Técnicas como posturas de yoga, regulação da respiração, relaxamento e meditação têm sido crescentemente investigadas cientificamente. Muitos destes estudos são realizados na Índia, onde a maior parte destas práticas se originou. Este artigo apresenta um relato de experiência profissional envolvendo um estágio de pesquisa no Departamento de Pesquisas em Yoga da Universidade de Patanjali, Índia, onde alguns destes estudos têm sido conduzidos. Os resultados apresentados, os quais derivam das investigações realizadas no referido departamento, indicam que tais práticas podem ter implicações clínicas para a saúde mental e física. Concernente à fisiologia, dependendo da técnica em particular, os benefícios podem ser notados durante, logo após ou algum tempo depois da prática. Similarmente, tanto interven-

Endereço para correspondência: Ramiro Barcelos, 2600, sala 105, Porto Alegre, RS, Brasil 90035-003. E-mail: menezescarolina@hotmail.com, lisiane.bizarro@gmail.com e shirleytelles@gmail.com

This research was supported by the National Council for Scientific and Technological Development (CNPq/Brazil). 
ções de curto e longo prazo podem produzir mudanças terapêuticas positivas. Entretanto, isto não é consistente em todas as condições, por isso a necessidade de investigar sistematicamente as aplicações das técnicas. Mudanças psicofisiológicas parecem acompanhar muitos destes efeitos e esta é uma área que precisa ser mais explorada, constituindo-se como um campo emergente, especialmente no Brasil, ligando o estudo entre as referidas técnicas, a psicologia e a neurociência.

Palavras-chave: Psicofisiologia, yoga, respiração, meditação.

\section{Yoga, Psicofisiología y Salud: Investigación del Departamento de Estudios del Yoga, Patanjali Universidad, India}

\section{Resumen}

Técnicas tales como posturas de yoga, la regulación de la respiración, relajación y meditación vienen siendo cada vez más investigadas científicamente. Muchos de estos estudios se han llevado a cabo en la India, donde la mayoría de estas prácticas se originó. Este artículo presenta un relato de experiencia de trabajo durante una pasantía de investigación en el Departamento de Investigación de Yoga de la Universidad de Patanjali, India, en el cual algunos de estos estudios han sido realizados. Los resultados presentados, que se derivan de las investigaciones en ese departamento, indican que tales prácticas pueden tener implicaciones clínicas para la salud mental y física. En cuanto a la fisiología, dependiendo de la técnica en particular, los beneficios pueden ser observados durante, inmediatamente después, o algún tiempo después de la práctica. De manera similar, tanto medidas de tratamiento a corto y largo plazo pueden producir cambios positivos. Sin embargo, esto no es consistente en todas las condiciones, lo cual justifica la necesidad de investigar sistemáticamente las aplicaciones de dichas técnicas. Cambios psicofisiológicos parecen acompañar a muchos de estos efectos siendo esta una área que requiere más investigación, especialmente Brasil, estableciéndose como un campo emergente que une la psicología y la neurociencia.

Palabras clave: Psicofisiología, yoga, respiración, meditación.

Techniques such as yoga postures (asanas in Sanskrit), regulated breathing (also called pranayamas in Sanskrit), relaxation, and meditation have increasingly become investigated in mainstream science. Even though their benefits are well documented in ancient texts (Taimini, 2006), it is relatively recently that health professionals have been systematically trying to understand how these practices can help in mental and physical conditions, or facilitate self-development, fostering well-being. Their origins lie in Eastern philosophies; therefore, it is not surprising that many of the scientific studies conducted in this field come from India.

The description given below is based on a research internship completed by the first author (CM) at the Yoga Research Department, in Patanjali University, in Haridwar, north India. In Patanjali University there are Yoga and
Ayurveda graduation courses and two research departments related to these respective areas. In addition, there is an Ayurvedic Hospital, and many inpatient and outpatient health services are offered to community. The internship was part of CM's doctoral training, which was carried out at the Laboratory of Experimental Psychology, Neuroscience, and Behavior ( $\mathrm{LPNeC}$ ), at the Federal University of Rio Grande do Sul (UFRGS), Brazil, with a scholarship from the Brazilian National Counsel of Technological and Scientific Development. The Yoga Research Department is directed by the third author (ST), who has graduated in Medicine, with a $\mathrm{PhD}$ in Neurophysiology. Currently, the department has collaborations with other research centers, such as the Department of Physiology of the Federal University of São Paulo, Brazil; the International Yoga Federation of Serbia, and the Institu- 
te of Physiology of the Medical University of Graz, Austria, as signed agreements. In addition, there are ongoing collaborations with other institutions such as the Biomedical Trust (UK), and the School of Health Science of the RMIT University Melbourne, Australia. Because the scientific study of yoga techniques is still modest in Brazil, the aim of this report is to present an overview of the Yoga Research Department, and some of the studies carried out there, including methods, design, equipment used, and results, in order to stimulate such initiatives in Brazilian research departments, and elucidate their relevance as well as the relationship between this field and psychology.

\section{Areas of Research}

The Department's main areas of research include studies related to the effects of yoga practices on (a) physiology, (b) human performance, (c) therapeutic outcomes, and (d) rehabilitation. Physiology encompasses the measurement of neurophysiological, autonomic, and metabolic variables, investigating whether these parameters vary or change during or immediately after the use of yoga postures, breathing, relaxation, and meditation (Telles \& Singh, 2011; Telles, Singh, \& Balkrishna, 2011). Human Performance comprises the behavioral assessment of alterations in attentional, perceptual, and motor skills as a result of these practices (Joshi \& Telles, 2009b). Therapeutic effects are evaluated when yoga-based interventions are carried out for the treatment of diverse conditions, such as obesity (a pre-morbid condition; Telles, Naveen, Balkrishna, \& Kumar, 2009), post-stress traumatic disorder (Telles, Singh, Joshi, \& Balkrishna, 2010), and anxiety (Telles, Gaur, \& Balkrishna, 2009), among others. In the area of rehabilitation, the efficacy of interventions is tested in groups such as the elderly and children with $\mathrm{Du}$ chenne muscular dystrophy (Manjunath \& Telles, 2007).

Currently, some of the projects underway include "A randomized trial on the effect of yoga and physical training on physical, cognitive, and emotional development in children (9-12 years of age)", "A randomized trial on the effect of yoga compared with metabolically matched walking on anthropometric and biochemical measures in obese people", "A randomized controlled trial of yoga therapy for persons with back pain and MRI proven herniated intervertebral disks", "Effect of right nostril breathing and breath awareness on oxygen consumption, energy expenditure, and autonomic variables", "Effect of a high frequency yoga breathing called Kapalabhati and breath awareness on energy expenditure, visual perception, and motor learning using an auto-tally Maze", "Immediate effect of $\mathrm{Ka}$ palabhati and breath awareness on concentration of blood oxy-hemoglobin and blood volume in healthy volunteers", and "Effect of a yoga-bellows type breathing called Bhastrika and breath awareness on reaction time".

\section{Laboratories}

There are four main laboratories in the Yoga Research Department. (a) In the Oxygen Consumption and Metabolic Testing Laboratory, research is carried out with the use of an open circuit metabolic analyzer, and a specially designed canopy to study oxygen consumed during breathing practices which involve nostril manipulation (Quark CPET, COSMED, Italy). (b) In the Autonomic Function Testing Laboratory, recordings are done on a 16 channel polygraph (Biopac System Inc., MP 150, USA), which measures oxygen saturation, heart rate variability (HRV), respiration (thoracic and abdominal), skin conductance response (SCR), non-invasive blood pressure (BP), cardiac output (CO), finger plethysmogram amplitude (FPA), among others. There is also a 2 channel polygraph (Biopac System Inc, MP 45, USA), used for measuring heart and breath rate. (c) The Clinical Neurophysiology Laboratory measures regional cerebral blood flow using a 16 channel Functional Near Infra-Red Spectroscopy (FNIR - Biopac System Inc, 1000, USA), neuroelectrical activity using Eletroencephalogram (EEG - Neurotravel Light ATES Medica Device, Italy), and Evoked Potential (Recorders and Medicare Systems, Chandigarh, India). Finally, (d) the Perceptual 
and Motor Skill Testing Laboratory measures fine motor skills (e.g., the Purdue pegboard), visual perception (e.g., the Müller-Lyer lines), reaction time (e.g., MOART Reaction Time), flexibility (e.g., Inclinometer), and muscular endurance (e.g., Hand Dynamometer). In parallel to these laboratories, research also includes Clinical Testing, such as body composition, anthropometry, biochemistry (e.g., variables such as the serum lipid profile, leptin and adiponectin), and immunology (e.g., NK cell counts in patients with cancer), whose analyses are outsourced (Religare, India).

\section{Method}

The search for articles focused on two main aspects: the representation of the four areas of study in the department, as well as the different techniques; and a time limit of five years, in order to gather the most recent and updated findings. Given the aim of the present work was to present the investigations carried out in the Yoga Research Department from Patanjali University, India, all the articles reviewed derive from such department.

\section{Results}

In addition to the projects underway, many others have already been concluded. Here, the most recent findings in the four main areas of research are presented.

\section{Physiology}

Many of the physiological investigations are concerned with the effects of breathing exercises, or pranayamas. These refer to the voluntary regulation of breathing, which are considered an important part of yoga practice, as they are believed to influence mind-body states. Respiration can be voluntarily modified in different ways, such as changing the rate and depth of breath, using different nostrils, holding the breath, doing contractions, and inhaling through the mouth among other methods (Telles \& Naveen, 2008).

Fifteen minutes of Kapalabhati (KPB, breathing at $1.0 \mathrm{~Hz}$ with forceful exhalation), pro- duced distinct changes in heart rate variability in healthy volunteers when compared to breath awareness (BA) in the same group (Telles, Singh, et al., 2011). More specifically, during KPB there was a decrease in the mean RR interval, NN50, pNN50, and an increase in respiratory rate, when compared to pre-intervention. PostKPB effects included a decrease in RR interval, and pNN50, compared to pre-intervention. During $\mathrm{BA}$, there was a significant increase in LF, and a decrease in HF compared with pre-intervention. After BA, compared to pre-intervention, a significant reduction in RR interval, and pNN50, an increase in LF, a decrease in HF, and a significant increase in $\mathrm{LF} / \mathrm{HF}$ ratio occurred.

Taken together, these results indicate that both exercises were related to reduced parasympathetic modulation, according to time domain analyses. Based on the relationship between sympathetic activation and vigilance (O'Connell et al., 2008), this result could explain why these techniques are associated with better selective and sustained attention (Telles, Raghuraj, Arankalle, \& Naveen, 2008). Additionally, in the frequency domain analysis, BA was also related to increased sympathetic modulation, indicating that slow conscious breathing could be helpful for achieving a relaxed, but attentive state. More importantly, these effects occurred both during the practice and remained for 15 minutes after the practice (Telles, Singh, et al., 2011).

In accordance with the relationship between sympathetic arousal and KPB, another study found that during this technique there was a significant increase in energy expenditure per minute, as well as in the energy derived from carbohydrates, and after the practice an increase in energy derived from fat occurred (Telles \& Singh, 2011). It is likely that sympathetic arousal is related to these increases, which in turn could influence the body cell mass, having important clinical implications. During BA there was a reduction in energy derived from fat, which could be reflecting a relaxed state followed by reduced energy expenditure.

Physiological data is also used to assess the effects of meditation. A particular type of meditation called dhyana, characterized by a state of 
mental expansiveness, has been associated with a decrease in heart rate, breath rate, and changes in both the frequency and time domain analyses of the HRV (Telles \& Raghavendra, 2011). These results indicate that in meditative states there is a shift towards vagal dominance.

\section{Human Performance}

The breathing exercises previously mentioned have also been tested concerning their effects on cognitive performance. For example, following KPB there was a significant reduction in the P300 peak latency, whereas after BA the P300 peak amplitude increased significantly (Joshi \& Telles, 2009b). One hypothesis is that the high frequency breathing, through heightened arousal, helps reduce the time required for this task, indicating better selective attention. As for BA, it has been hypothesized that this exercise helps increasing the neural resources available for the attentional task. This could be facilitated by a parasympathetic dominance, resulting in a restful alert state, different from the stimulating effects Kapalabhati seems to produce.

Likewise, these two types of exercises also seem to improve visual perception, indicated by a decrease in the degree of optical illusion, as assessed by the Müller-Lyer linesi (Telles, Maharana, Balrana, \& Balkrishna, 2011). Importantly, practice effects were ruled out by the use of a control group, in which no difference was found. It was hypothesized that the observed changes may come about through cognitive-judgmental factors that are influenced by attention and awareness.

Human performance can also help understand some of the effects of meditation practice. Dharana, another type of meditation characterized by focusing on a single object, such as the syllable OM, resulted in significant improvements in selective and sustained attention, as measured by the Letter Cancelation Task (Telles \& Raghavendra, 2011). Therefore, meditation (Telles \& Raghavendra, 2011), as well as BA (Telles, Maharana, et al., 2011), seem to involve a combination of attention and sympathetic modulation.

\section{Therapy}

Yoga-based programs, including a combination of techniques - physical postures, breathing, relaxation, and meditation - have been tested for different conditions, such as obesity as a premorbid condition (Telles, Naveen, et al., 2009), rheumatoid arthritis (Telles, Naveen, Gaur, \& Balkrishna, 2011), post traumatic stress disorder (Telles et al., 2010), anxiety (Telles, Gaur, et al., 2009), among others. Even though each of these techniques seem to have effects that are likely beneficial for clinical symptoms, it is important to systematically test their combination in interventions for particular health conditions.

For example, it has been demonstrated that an intensive 6 days intervention, with 5 hours practice combining yoga and a lacto-ovo-vegetarian diet, may not be the best alternative for obese people (Telles, Naveen, et al., 2009). Following this training, participants decreased body mass index, but this was accompanied by a decrease in lean muscle mass, water content, and HDL levels. Although some improvements were also observed, such as a decrease in fasting serum leptin levels, waist and hip circumference, and an increase in postural stability and bilateral hand grip strength, the decreases accompanying body mass index loss are not beneficial, and longer-term programs remain to be investigated.

More positive results have been obtained with a one week yoga intervention, comprising two daily sessions, for people with rheumatoid arthritis (Telles, Naveen, et al., 2011). There was a reduction in the disability index score, as well as rheumatoid factor levels, and an increase in the bilateral hand grip strength in male participants. Taken together, these findings suggest such interventions can be beneficial to rheumatoid arthritis patients, by improving their level of functioning and immune parameters.

Psychological conditions also seem to benefit from such interventions. After one month of the Bihar floods, survivors were offered one week of yoga practice, with a one hour session daily, to help them in stress management (Telles et al., 2010). Despite no change in heart rate 
variability, nor breath rate, the yoga participants showed a significant decrease in sadness, whereas the control group had a significant increase in anxiety levels. Similarly, improvements in self-report state anxiety were also observed after volunteers with stress as a presenting complaint attended a single yoga session (Telles, Gaur, et al., 2009).

\section{Rehabilitation}

In this area of research, yoga-based interventions are tested for people who present some type of impairment, but who are not necessarily ill. For example, a 6 months yoga intervention was offered to elderly people, to help them gain better control over their posture and balance (Manjunath \& Telles, 2007). Classes were held 6 days a week, lasting 75 minutes. Pre-post analyses after 6 months showed that the yoga group had increased overall scores for gait and balance, as well as a decrease in the number of steps taken to complete the mobility test, which was not seen in the control group. The mechanisms may include improved joint ability, muscle strength, and visual perceptual sensitivity (Manjunath \& Telles, 2007).

\section{Final Considerations}

The results presented above, which represent the investigations carried out in the Yoga Department Research from the Patanjali University, India, indicate that techniques such as yoga postures, regulated breathing, relaxation and meditation can have clinical implications for mental and physical health. Additionally, they elucidate the variety of areas, designs, and outcome measures that can be considered when studying these practices. Concerning physiology, depending on the particular technique, benefits are seen during, immediately after or some time following the practice. Likewise, both short and long term interventions may produce positive therapeutic changes. However, this is not consistent for all conditions, hence the need to systematically investigate their applications for different clinical groups.
In addition to testing therapeutic effects with randomized controlled trials, it has been discussed that reducing inter-individual variability is an important issue when studying the physiology of certain techniques in healthy volunteers. Thus, a self-control design, in which the same individual is assessed in repeated sessions (e.g., meditation and non meditation) on separate days should be considered (Joshi \& Telles, 2009a). Nonetheless, the number of sessions should be small, in order to avoid carry over effects.

Finally, psychophysiological changes seem to accompany many of these effects and this is a field that warrants more investigation, especially in Brazil, where this area of research is still scarce. In this regard, it should be noted that this is an emergent field, which represents an important interface between psychology and neuroscience, combining both basic and applied research.

\section{References}

Joshi, M., \& Telles, S. (2009a). Effect of four voluntary regulated yoga breathing techniques on grip strength. Perceptual and Motor Skills, 108, 1-7. doi: 10.2466/PMS.108.3.2009

Joshi, M., \& Telles, S. (2009b). A Nonrandomized nonnaive comparative study of the effects of $\mathrm{Ka}$ palabhati and Breath Awareness on event-related potentials in trained yoga practitioners. The Journal of Alternative and Complementary Medicine, 15(2), 1-5. doi: 10.1089/acm.2008.0250

Manjunath, N. K., \& Telles, S. (2007). Effects of Yoga and an Ayurveda preparation on gait, balance and mobility in older persons. Medical Science Monitor, 13(8), CR339-348.

O'Connell, R. G., Bellgrove, M. A., Dockree, P. M., Lauc, A., Fitzgerald, M., \& Robertson, I. H. (2008). Self-Alert Training: Volitional modulation of autonomic arousal improves sustained attention. Neuropsychologia, 46, 1379-1390. doi: 10.1016/j.neuropsychologia.2007.12.018

Taimini, I. K. (2006). A ciência do Yoga. Brasilia, DF: Teosofica.

Telles, S., Gaur, V., \& Balkrishna, A. (2009). Effect of a Yoga practice session and a Yoga theory session on state anxiety. Perceptual and Motor Skills, 109(3), 1-7. doi: 10.2466/PMS.109.3.2009 
Telles, S., Maharana, K., Balrana, B., \& Balkrishna, A. (2011). Effects of high-frequency yoga breathing called Kapalabhati compared with Breath Awareness on the degree of optical illusion perceived. Perceptual and Motor Skills, 113(1), 1-10. doi: 10.2466/02.20.22.PMS.113.4.2011

Telles, S., \& Naveen, K. V. (2008). Voluntary breath regulation in yoga: Its relevance and physiological effects. Biofeedback, 36(2), 70-73.

Telles, S., Naveen, K. V., Balkrishna, A., \& Kumar, M. (2009). Short term health impact of a yoga and diet change program on obesity. Medical Science Monitor, 15(12), CR1-CR6.

Telles, S., Naveen, K. V., Gaur, V., \& Balkrishna, A. (2011). Effect of one week of yoga on function and severity in rheumatoid arthritis. BioMed Central Research Notes, 4(118). Retrieved November 12, 2011, from http://www.biomedcentral.com/1756-0500/4/118

Telles, S., \& Raghavendra, B. R. (2011). Neurophysiological changes in meditation correlated with descriptions from the ancient texts. Biofeedback, 39(2), 56-59. doi: 10.5298/1081-5937-39.2.08

Telles, S., Raghuraj, P., Arankalle, D., \& Naveen, K. V. (2008). Immediate effect of high frequency yoga breathing on attention. Indian Journal of Medical Sciences, 62(1), 20-22.
Telles, S., \& Singh, N. (2011). High frequency yoga breathing increases energy expenditure from carbohydrates. Medical Science Monitor, 17(9), 7-8.

Telles, S., Singh, N., \& Balkrishna, A. (2011). Heart rate variability changes during high frequency yoga breathing and breath awareness. BioPsychoSocial Medicine, 5(4). Retrieved November 11, 2011, from http://www.bpsmedicine. com $/$ content $/ 5 / 1 / 4$

Telles, S., Singh, N., Joshi, M., \& Balkrishna, A. (2010). Post traumatic stress symptoms and heart rate variability in Bihar flood survivors following yoga: A randomized controlled study. BioMed Central Psychiatry, 10(18). Retrieved November 13, 2011, from http://www.biomedcentral.com/1471-244X/10/18
Recebido: 08/01/2013

$1^{a}$ revisão: 11/03/2013

Aceite final: 19/03/2013 